\title{
Methodology of Formation of Economic Relations in Agro-Industrial Complex
}

\author{
Medelyaeva Z.P.* \\ Economic department \\ Voronezh State Agrarian University named after Emperor \\ Peter the Great \\ Voronezh, Russia \\ e-mail: medelaeva@mail.ru \\ Shilova N.P. \\ Economic department \\ Voronezh State Agrarian University named after Emperor \\ Peter the Great \\ Voronezh, Russia \\ e-mail: shilova_np@mail.ru
}

\author{
Pankratova L.D. \\ Economic department \\ Voronezh State Agrarian University named after Emperor \\ Peter the Great \\ Voronezh, Russia \\ e-mail: larochka567@mail.ru \\ Lyashko S.M. \\ Economic department \\ Voronezh State Agrarian University named after Emperor \\ Peter the Great \\ Voronezh, Russia \\ e-mail: sergei.ljashko@econiva-apk.com.
}

\author{
Malikov I.A. \\ Department of Information Technology in agriculture \\ Tadjik agricultural university named after Sh.Shotemura \\ Dushanbe, Tajikistan \\ e-mail: inom_1969@inbox.ru
}

\begin{abstract}
The activity of the agro-industrial complex is determined both by the available resources (land, labor, fixed and current assets), the technologies used, the scientific and technical potential, and the existing production and economic relations in the system, which is the agro-industrial complex. Production and economic relations, in turn, are determined by the organizational and economic mechanism, which includes tools, methods and means of influencing market players. Many market players are involved in the sphere of joint activities and it is the economic mechanism that should ensure equal cooperation in order to fulfill the goals set for ensuring the country's food security, as the main task of the state.
\end{abstract}

Keywords - agro-industrial complex; economic mechanism; economic relations; logistics approach; structuring of agroindustrial complex.

\section{INTRODUCTION}

The authors of many scientific papers [1-5] have noted the need to improve the efficiency of the functioning of the agroindustrial complex (agro-industrial complex), including by defining a clear development strategy, developing an organizational and economic mechanism that allows creating conditions for the expanded development of all of its economic entities.

The formation of an effective economic mechanism can be defined as a certain type of innovation, which, unlike technical and technological ones, does not require financial resources, but its implementation is associated with certain difficulties, as it is tied to the alterations in the organization of production, labor, wages, behavior of specialists, business culture and etc. Building an effective market-oriented strategy requires defining a procedure that can use all of these elements in the relationship between business entities in the agro-industrial complex.

In our understanding, the economic mechanism is a way of interrelations between heterogeneous elements of the agroindustrial complex for solving the key problem - providing the society with high-quality food products in accordance with medical standards. The AIC has inherent mechanisms of exchange and distribution, which link the production and the consumption. Economic mechanisms are determined by the legislative and regulatory framework in which they operate and have certain features in different formations and at certain stages of state development. There are various methodological approaches to the formation of the principles of the economy and their use for orientation in determining the coordinates of the organizational and economic mechanism for the development of the agro-industrial complex.

\section{ANALYSIS}

At the present stage, many business entities are involved in the scope of joint activities within the boundaries of the agroindustrial complex, and for their effective functioning it is necessary to define an economic mechanism that, on the one hand, would provide equally beneficial cooperation, and on the other hand, would contribute to the fulfillment of the goals of life support and development in the market economy. Subjects in the agro-industrial complex are various legal 
entities and individuals, united in a logistic system with the aim of achieving a common goal - meeting social needs. Besides, the organizational and economic mechanism of the AIC should serve as the means of ensuring a flexible and synchronous interaction of all participants in the AIC with the nature, with the functioning of bio-systems, social, financial, information systems that obviously present certain risks [6].

The main objective of the agro-industrial complex is determined by the external environment, since it satisfies the consumer demand of the population for final products produced from agricultural raw materials by enterprises in the processing sector. This goal defines the targets for each subject of the agro-industrial complex and the fulfillment of a common goal is ensured under the conditions that the goods are produced in the amount, assortment and price that would satisfy the needs of the society. Thus, the companies of the agro-industrial complex in the process of production activities should form the supply of finished products for the food market, taking into account consumer demand and its dynamics. Besides, the participants of the agro-industrial complex can and should actively affect the consumer demand, expanding the range of products, improving quality, reducing prices. If these conditions are met, the participants of the agroindustrial complex can reach higher targets not only satisfying, but also forming the consumer demand for new types of food products. Achieving the aim of satisfying the social needs, the economic mechanism should ensure the goal of selfpreservation of the AIC as a system.

\section{RESULTS}

The mechanism of AIC goals formation and realization as understood by the authors is presented in the Figure 1.

The formation and implementation of the agro-industrial complex goals requires the interaction of the two parties: aggregate consumers satisfying their needs through the food market, and aggregate producers interacting on different issues within the agro-industrial complex.

The relations of producers of agricultural raw materials, processing enterprises and consumers of finished products are determined by the consumer value of food (quality, ecological purity, diversity, etc.). AIC as a manufacturer of products should study the food market, since profit making (the main goal of all AIC participants) is possible only if there is information on the volumes of consumption, import of similar products, and the degree of customer satisfaction. Information on market conditions, prices of agricultural raw materials and finished products, the size of government support, etc. is important. Competition, which takes place among the participants of the agro-industrial complex, implies that the offer price for products offered by manufacturers is within an acceptable framework of market prices and solves the problem, on the one hand, of meeting the consumer demand, and on the other, of ensuring the necessary level of profitability for the participants of the agro-industrial complex.

The external environment is larger and stronger than the internal environment of any organizational system, including the agro-industrial complex. The consumer, who determines the food market, is in an asymmetric relationship with the supplier (enterprises of the agro-industrial complex): the consumer only defines the tasks for the supplier, and the latter must satisfy the formed demands of the society, that is, has obligations to the consumer, the fulfillment of which will provide the income required for the operation of the enterprises of the agro-industrial complex. The environmental factors that influence the state and structure of the agroindustrial complex are multi-aspect, they can be classified as: economic, influencing through the market, social, determining the order through society, and the state, natural, formed by natural and climatic conditions. The means of ensuring rationality and consistency of the interaction of all participants in the agro-industrial complex under the influence of the above factors should be the economic mechanism, which largely determines the potential of the agro-industrial complex, its efficiency, the possibility of expanded reproduction, competitiveness in the domestic and world markets.

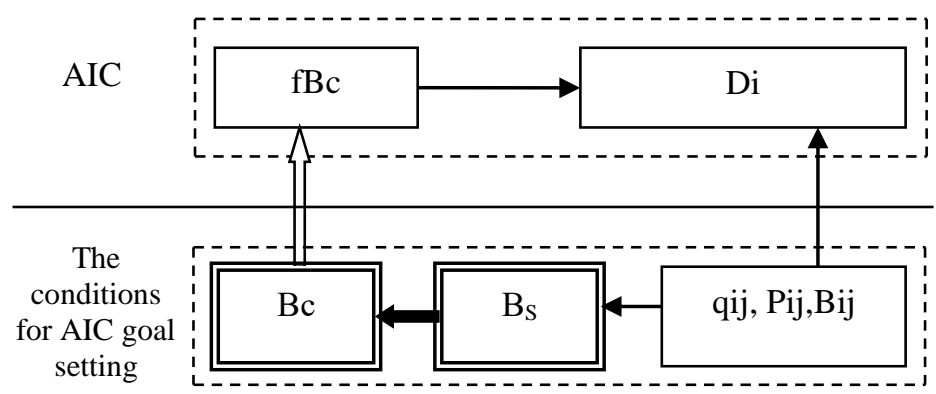

Fig. 1. The mechanism of AIC goals formation and realization [7]

$\mathrm{Bc}-$ consumer demand for the finished goods;

$\mathrm{fBc}$ - AIC goal: satisfaction consumer's demand for the finished AIC goods;

Di - AIC goal: obtaining (Di) by each i-th AIC participant;

$\mathrm{n}$ - number of AIC subjects;

qij, Pij, Bij - the conditions for AIC goals achievement in terms of (qij), price (Цij) and amounts (Bij) of the produced goods (j) and services for all AIC participants;

$\mathrm{m}$ - amount of the goods and services in AIC;

$\mathrm{B}_{\mathrm{S}}$ - food supply;

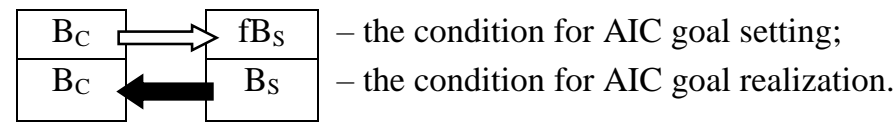

The logistic concept of the agro-industrial complex defines the requirements of adaptive dynamism for food complexes, since the external environment is constantly changing and the full value of the logistics chain, when to obtain a finished product all stages of sequential and related processes that convert agricultural raw materials into finished products and promote them to the consumer must be involved. Consequently, the economic mechanism of the formation of the AIC should initially contain such properties as amorphousness and totality. 
Amorphousness implies the state of the structure of the agro-industrial complex, which does not have a permanent frame, permanent boundaries and permanent composition of participants, which in certain periods to achieve common goals of the agro-industrial complex can move, sometimes from the internal environment to the external, or vice versa.

The totality of the AIC as a system assumes the spatial form with the internal functional filling. The total system develops by improving and replenishing the elements of the system, allowing it to function better.

Defining the AIC as a system with properties of adaptability and totality, we consider the food complex as a multi-level system in which any processes are not possible without interconnections and economic relationships between enterprises doing business in a common system in which they are technologically and economically dependent.

The process of agro-industrial complex functioning as an adaptive total system tends to integrate, and centralization takes place in the mechanism of its formation, contributing to the solution of common tasks, but not destroying the market economy. Integration is conditioned by the objective necessity of uniting the subjects of the agro-industrial complex with the aim of obtaining a multiplicative effect by individual participants, since it is associated with objective economic laws and subjective rationality from the point of view of profitability for the participants. Defining the methodological foundations of the economic mechanism of the formation of the agro-industrial complex, it is advisable to analyze its relationship with the external environment from the point of view of "openness - closeness". At the present stage, when the external environment is dynamically changing, it is advisable to present the agro-industrial complex as an open system. At the same time, the AIC is considered at the same time as a mechanical and organic system, which contains large amount of variables, not always controlled, not exposed to the changes within the system. The economic mechanism should contribute to the construction of mutually beneficial relationships under any conditions of "openness - closeness", but the levers and methods will differ. In a closed system, the relationship will be, as a rule, regulated and will be based on functional obligations. Other distinctive features for building relationships for the two systems are reflected in Table I.

AIC can be represented as a system of organizationally interdependent parts, which interacts with the external environment, determining the success or failure of all participants in the system. It is important to correctly define the institutional bases of the state in the system of mutual relations of the agro-industrial complex with elements of the external environment that determine the activity of the agroindustrial complex and which the agro-industrial complex does not control and can not influence. These are, for example, food consumption standards established by medical requirements, bio-systems, various standards, consumer preferences, climatic conditions, market demand and supply, exports, imports, etc.

There are natural carriers of relations between producers and enterprises processing agricultural products in the agroindustrial complex. There are also two stages of integration: the first is characterized by the relationship between producers and processing enterprises based on the logistic concept of agricultural production, storage, delivery to processing enterprises, processing of raw materials, production ready for sale to the consumer. Taking into account the specifics of agricultural products (its composition is heterogeneous, we have the use of by-products), each specific kind of it can be the raw material not for one, but for several industries engaged in industrial processing. At the same time, there are relationships not only with regard to the use of primary agricultural raw materials, but also by-products, which we identified as second-order links.

TABLE I. REGULATION OF THE INTERACTIONS WITHIN THE AIC ECONOMIC MECHANISM UNDER THE CONDITIONS OF "OPENNESS - CLOSENESS"

\begin{tabular}{|c|c|c|}
\hline Indicators & Closeness of the system & Openness of the system \\
\hline Features & Mechanic system & Organic system \\
\hline $\begin{array}{l}\text { Environment } \\
\text { conditions }\end{array}$ & Stable & Changing \\
\hline $\begin{array}{l}\text { Inter- } \\
\text { connection } \\
\text { and } \\
\text { interaction } \\
\text { types }\end{array}$ & $\begin{array}{l}\text { - tendency for vertical } \\
\text { interaction of the business } \\
\text { entities; } \\
\text { - internal environment } \\
\text { perception; } \\
\text { - concentration of the } \\
\text { information at the top levels } \\
\text { of hierarchy; } \\
\text { - the priority of the final } \\
\text { goal achievement; } \\
\text { - differentiation of the } \\
\text { functional tasks among the } \\
\text { participants; } \\
\text { - hierarchic system of } \\
\text { power and subordination; } \\
\text { - definition of the common } \\
\text { goal. }\end{array}$ & $\begin{array}{l}\text { - mostly horizontal } \\
\text { communication trends; } \\
\text { - correspondence between } \\
\text { the knowledge nature and the } \\
\text { common goal of the system; } \\
\text { - the priority of the } \\
\text { individual goals as the } \\
\text { elements for the achievement } \\
\text { of the common goal; } \\
\text { - solution of the individual } \\
\text { tasks through the prism of the } \\
\text { common interests; } \\
\text { - sanctions for the breach of } \\
\text { the common interests of the } \\
\text { participants within the } \\
\text { system; } \\
\text { - the priority of the } \\
\text { information and } \\
\text { recommendations over } \\
\text { instructions. }\end{array}$ \\
\hline
\end{tabular}

In the agro-industrial complex, it is not always easy to achieve the required level of controllability, analysis, control, efficiency when considering the multiplicity of economic processes that will be in three areas of this complex. At the present stage, the processes occurring in the agro-industrial complex, their scale requires improvement, including that in management. In this regard, one of the tasks in building the economic mechanism is the correct structuring of food subcomplexes in the agro-industrial complex, identifying links that ensure the effect due to the "looping" of production processes based on the use of certain agricultural raw materials. In this we agree with O.A. Rodionova, who justified the need to link the organizational and economic structure and the development of an appropriate economic mechanism [8].

When structuring the agro-industrial complex, it is necessary to correctly identify those sectors that most use the connections in the agro-industrial complex, and will help to fully utilize the resources of agricultural enterprises, utilize the production capacities of processing enterprises, and produce finished products that are necessary for the domestic and global markets [9-11]. V. Shatokhin believes that such production structures can be sugar and dairy plants, as the 
dairy and beet-sugar production in full use of the resources of agricultural producers, forms the necessary integration base [12]. Among the processing enterprises, the sugar and dairy factories using raw materials produced by all agricultural producers should become industrially developed and complexforming entities in many regions.

The integrated development of regional agro-industrial complexes will contribute to increasing the competitiveness of both the region as whole and individual enterprises due to the growth of economic and financial indicators that demonstrate the effectiveness of their activities [13-15].

Currently, not all agricultural producers are engaged in dairy cattle breeding. Our calculations and the solution of economic and mathematical problems of optimizing sectoral structures at district levels show that it is possible to develop livestock in many regions of the Central Black Soil Region and bring the livestock of dairy herds to the level of 1995 with the productivity of 6-7 thousand $\mathrm{kg}$. There are sufficient agricultural land and labor resources for this, but in most cases it is necessary to build new production facilities.

\section{CONCLUSION}

The development of sugar beet and dairy sub-complexes will contribute to the diverse and multidirectional flows of natural carriers of integration ties in regional AIC.

\section{References}

[1] A.V. Agibalov, Y.V. Tkacheva, L.A. Zaporozhtseva, "International Journal of Economic Perspectives", Improvement of the financial manag. strategy for agricult. Enterprises, vol. 11, no. 3, pp. 1686-1696, 2018

[2] S.A. Gorlanov, Z.P. Medelyaeva, V.B. Malitskaya, M.B. Chirkova, E.I. Kostyukova, "Content analysis the term "effectiveness" and the concepts of its quantitative characteristics", Indo Amer. J. of Pharmac. Sci., vol. 6, no. 3, pp. 5293-5298, 2019.

[3] V.G. Zakshevskiy, I.F. Khitskov, O.G. Charykova et al., "Strategic directions for agricultural development in the Voronezh region.
Voronezh: Res. Instit. of econ. and organizat. and agro-industr. complex of the Central Black-soil area of Russ., 2017, 212 p.

[4] M.E. Otinova, Z.V. Gavrilova, Mechanism of interaction between agricultural entrepreneurship and the state. Voronezh: FSBNU NIIEOAPK Central Bank of Russ., 2018, 154 p.

[5] O.G. Charykova, E.S. Markova, "Regional Clustering in the Digital Economy", Econ. of the reg.: sci. inform. and analyt. Econ. J., vol. 15, iss. 2, 2019. DOI: $10.17059 / 2019-2-8$

[6] V.G. Zakshevsky, O.G. Charykova, I.N. Merenkova, "Strategic priorities for developing the agro-industrial complex and rural areas of the region", IOP Conf. Ser. Earth and Environ-mental Sci. electr. Resource, p. 012007, 2019. DOI: 10.1088/1755-1315/274/1/012007

[7] Z.P. Medelyaeva, Economic relations in the agro-industrial complex: theory, methodology, practice. Monograph. Voronezh: Voronezh state agricult. Univer., 2008, 292 p.

[8] O.A. Rodionova, "Transfer prices in the economic relation system within integrated formations", Econ. of agricult. and processing enterprises, no. 10, pp. 46-47, 2000.

[9] O.G. Charykova, E.V. Zakshevskaya, E.V. Salnikova, E.A. Popova, N.Y. Polunina, Infrastructure of the agrofood market: theory, analysis, concept, ed. by O.G. Charykova. Voronezh: FSBNU NIIEOAPK CR of Russ., 2019, $140 \mathrm{p}$.

[10] V.G. Zakshevsky, O.G. Charykova, "Expansion of competitive positions in the agro-food market: regional aspect", Mezhdunarodnyj selskohosjaistvennyj zhurnal, vol. 5, no. 371, pp. 50-55, 2019. DOI: 10.24411/2587-6740-2019-15085

[11] M.E. Otinova, T.V. Zakshevsky, M.V. Zagvoskin, "Mechanism of interaction between the state and agrarian entrepreneurship: organizational and economic aspects", Vest. Voronezhskogo agrarnogo univer., vol. 2, no. 57, pp. 140-150, 2018.

[12] M.V. Shatokhin, "Integration of agricultural and processing enterprises as a factor of competitiveness improvement", Econ. of agricult. and processing enterprises, no. 6, pp. 47-48, 2004.

[13] S. Stanciu, F.O. Virlanuta, O.A. Vochin et al., "Fast Moving Consumer Goods (Fmcg) Market In Romania Features And Trends", Amfiteatru Econ., vol. 21, spec. iss. 13, pp. 778-794, 2019.

[14] T.V. Sarycheva, L.P. Bakumenko, M.N. Shvetsov, "Assessment of The Competitiveness of Economic Activities of the Region in Terms of Employment", Mediterranean J. of Soc. Sci., vol. 6, no. 3, pp. 119-126, 2015.

[15] M. Kostić, L. Maksimović, B. Stojanović, "The limitations of competition in the insurance markets of Slovenia, Croatia and Serbia", Econ. Res.-Ekonomska Istraživanja, vol. 29, no. 1, pp. 395-418, 2016. DOI: $10.1080 / 1331677 X .2016 .1169703$. 